DOI: $10.21802 /$ artm.2020.3.15.17.

УДК 615.281.9 / 615.076.7

\title{
ДОСЛІДЖЕННЯ ЧУТЛИВОСТІ КЛІНІЧНИХ ШТАМІВ S. AUREUS ДО АНТИСЕПТИКА ДЕКАМЕТОКСИНУ ТА МІСЦЕВИХ АНЕСТЕТИКІВ
}

\author{
Ю.М. Бабіна ${ }^{1,2}$, О.А. Назарчук ${ }^{1}$, Д.В. Дмитрієв ${ }^{2.3}$, О.В. Римша ${ }^{1}$, М.А. Бегма ${ }^{1}$
}

Вінницький наиіональний медичний університет ім. М.І. Пирогова,

${ }^{1}$ кафедра мікробіологї̈,

${ }^{2}$ кафедра анестезіології, інтенсивної терапії та медииини невідкладних станів;

${ }^{3}$ Вінницький обласний клінічний високоспеціалізований ендокринологічний центр, м. Вінниця, Украӥна, ORCID ID: 0000-0003-4399-5178, e-mail: ulianababina1989@gmail.com,

ORCID ID: 0000-0001-7581-0938, e-mail: nazarchukoa@gmail.com,

ORCID ID: 0000-0001-6067-681X, e-mail:dmytrodmytriiev@gmail.com,

ORCID ID: 0000-0002-2718-0246,e-mail:rymsha_av@ukr.net,

ORCID ID: 0000-0001-8433-9420

Резюме. Відомо, що близько 65-85 \% усіх інфекційних захворювань спричинені бактеріями, які мають здатність до формування біоплівок.

Мета дослідження - вивчити формування біоплівок in vitro штамами S. aureus та визначення їх чутливості до місцевих анестетиків окремо та в комбінації з антисептиком декаметоксином.

Матеріали та методи. Активність місцевих анестетиків (бупівакаїн $0,5 \%$, лідокаїн $2 \%$, ропівакаїн $0,75 \%)$ досліджували на клінічних штамах $S$. aureus $(\mathrm{n}=31)$ якісним диско-дифузійним методом 3 використанням стандартних стерильних паперових дисків, просочених ex tempore клінічними дозами препаратів. Як контроль використовували антисептик декаметоксин $0,01 \%$. Вивчено здатність S. aureus продукувати біоплівки в присутності клінічних концентрацій місцевих анестетиків на поліуретанових катетерах та за оптичною щільністю (ОЩ) біоплівок у 96-лунковому планшеті з подальшим фарбуванням кристал віолетом (за Christensen, 1985).

Результати. Локальні анестетики проявляли протистафілококову дію, яка поступалась протимікробній дії декаметоксину. У присутності $1,0 \%$ лідокаїну та 0,125 \% бупівакаїну мало місце пригнічення плівкоутворення $S$. aureus в 0,778 та 0,776 разів відповідно, а середній показник плівкоутворення $S$. aureus зростав у присутності $0,375 \%$ ропівакаїну та $0,25 \%$ бупівакаїну в 1,308 та 1,206 разів відповідно.

Висновки. Культура $S$. aureus має виражену здатність до формування біоплівок на медичних виробах. Клінічні штами $S$. aureus, які колонізують полімерні поверхні медичних засобів володіють високою чутливістю до декаметоксину. Місцеві анестетики бупівакаїн, лідокаїн володіють вираженими антимікробними властивостям щодо ізолятів $S$. aureus, пригнічують утворення ними бактеріальної біоплівки, в порівнянні з низькою антистафілококовою дією ропівакаӥну.

Ключові слова: анестетики, антисептики, біоплівка, мікроорганізми, S. Aureus.

Ветуп. Поява та поширення бактерій, стійких до протимікробних препаратів, $є$ однією з найсерйозніших загроз для здоров'я населення. У порівнянні 3 інфекціями, спричиненими чутливими штамами, інфекції, викликані резистентними до антибіотиків організмами (стійкі до ванкоміцину Enterococcus spp. (VRE) та Staphylococcus aureus) з більшою ймовірністю подовжують термін госпіталізації, підвищують ризик смерті і потребують лікування більш токсичними або коштовними антибіотиками [10].

Пацієнти, які знаходяться на тривалому лікуванні в закладах охорони здоров'я, - це основна категорія хворих з високим ризиком інфікування антибіотикорезистентними патогенами. За даними зарубіжних досліджень, інфекція, пов'язана з їх госпіталізацією, виникає у 5-10 \% пацієнтів, що призводить до більш, ніж 90000 смертей на рік в США [10]. Переважна більшість інфекцій, пов'язаних 3 наданням медичної допомоги, спричинена бактеріями 3 високою стійкістю, такими як метицилін-резистентний
S. aureus (MRSA) i VRE. Зокрема, MRSA асоціюється зі значною захворюваністю і смертністю серед стаціонарних хворих, що складає $35-80$ \% від загальної стафілококової інфекції [11].

На сьогодні однією 3 провідних перешкод ефективної антибіотикотерапії вважають здатність до плівкоутворення клінічними штамами умовнопатогенних мікроорганізмів. Стафілококи, представники родини Enterobacteriaceae та $P$. aeruginosa є найбільш відомими патогенами, які здатні до плівкоутворення [12].

Встановлено, що завдяки плівкоутворенню бактерії набувають додаткового захисту від дії антибіотиків (у геометричній прогресії обмінюючись генами антибіотикорезистентності), більш стійкі до факторів імунної відповіді хазяїна та фізичних, біологічних та хімічних чинників (ультрафіолетове опромінення, іони металів, анаеробні умови, кислотність, солоність, зміна $\mathrm{pH}$, висушування, бактеріофаги та ін.), а також здатні виділяти ендотоксини в матрикс 
біоплівок, а потім у навколишнє середовище [4, 5]. У формуванні біоплівок бере участь велика кількість внутрішніх елементів (структур) бактерій. Так, для S. aureus велике значення має PIA (Polysaccharide Intracellular Adhesin) - полісахарид, який сприяє адгезії; цьому ж етапу сприяє $\alpha$-токсин, який кодується геном hla (версія гену МНC - головний комплекс гістосумісності); велике значення мають тейхоєві кислоти, ВАР-білки та ін. [2, 3].

Обгрунтування дослідження. Незважаючи на значні успіхи, що були досягнуті в лікуванні внутрішньолікарняної інфекції, рівень захворюваності та розвитку інфекційних ускладнень залишається високим. Відомо, що мікроорганізми, а особливо клінічні ізоляти $S$. Aureus, здатні колонізувати медичні імпланти, ендоваскулярні, перидуральні та сечові катетери, інтубаційні трубки. Розширення використання різноманітних сучасних інвазивних матеріалів та пристроїв у відділеннях інтенсивної терапії та хірургії вказує на зростання проблеми інфекційних ускладнень у медичній практиці. Мікроорганізми, здатні утворювати біоплівки, спричиняють вентиляторасоційовані пневмонії, катетер-асоційованої інфекції кровотоку та сечової системи, сепсису [13]. До $60 \%$ інфекцій (дихальної системи, сечової системи, ендокардити тощо) викликають біоплівкові форми бактерій [12].

Правильний вибір антибіотиків та рання цілеспрямована етіотропна терапія можуть забезпечити ліквідацію збудників та подолання даного стану. За даними вітчизняних та зарубіжних досліджень, 3 використанням антибіотиків створюють місцеве покриття медичних імплантів, наприклад, ендоваскулярні та сечові катетери для запобігання мікробної колонізації та утворення ними біоплівок $[13,14]$. Проте, враховуючи ризик розвитку бактеріальної резистентності та алергічні реакції на антибіотики для профілактики інфекційних ускладнень, зберігає свою актуальність пошук альтернативних методів профілактики та лікування. За даними вітчизняних дослідників, місцеві антисептики, зокрема декаметоксин, володіють протимікробним ефектом на полірезистентні штами, а в комбінації з антибіотиками посилюють їх бактерицидний ефект [15], що являє практичний інтерес для подальших наукових досліджень.

Згідно $з$ результатами останніх зарубіжних досліджень у місцевих анестетиків (МА), крім лікування болю, доведено антимікробний ефект у стоматологічній практиці та в профілактиці інфекційних післяопераційних ускладнень [16]. Розширення знань щодо утворення біоплівок розповсюдженими збудниками та вивчення альтернативних методів профілактики та лікування інфекційних ускладнень має суттєвий науковий та практичний інтерес для розробки сучасних підходів попередження внутрішньолікарняної інфекції.

Мета дослідження: вивчити чутливість клінічних штамів S. aureus до місцевих анестетиків, антисептика декаметоксину та дослідити in vitro ïx вплив на формування збудником моновидових біоплівок.

Матеріали та методи. Для дослідження використовували клінічні штами $S$. aureus $(\mathrm{n}=31)$, виді- лені зі зразків центральних катетерів від хворих відділення анестезіології, реанімації та інтенсивної терапії. Активність місцевих анестетиків (бупівакаїн $0,25 \%, \quad 0,5 \%$, лідокаїн $1,0 \%, 2,0 \%$, ропівакаїн $0,375 \%, 0,75 \%$ ) досліджували на клінічних штамах S. aureus (n=31) якісним диско-дифузійним методом 3 використанням стандартних стерильних паперових дисків, імпрегнованих еx teтpore відповідними розчинами зазначених препаратів. Правильність методології була підтверджена контролем з використанням антисептика декаметоксину 0,01\%. Зони затримки росту мікроорганізмів, навколо дисків 3 анестетиками та декаметоксином на щільних поживних середовищах вимірювали через 24 год інкубації культур мікроорганізмів ( $\left.37^{\circ} \mathrm{C}\right)$.

У зазначених клінічних штамів золотистого стафілокока було додатково досліджено здатність продукувати біоплівки в присутності концентрацій анестетиків та декаметоксину, які були в 2-4 рази менші від мінімальних бактеріостатичних концентрацій. Останні визначали попередньо стандартним методом двократних серійних розведень. Біоплівки моделювали статичним способом у полістиролових 96-лункових планшетах за методом G. D. Christensen [7]. Добову агарову культуру штамів $S$. aureus розводили $0,9 \%$ розчином $\mathrm{NaCl}$ до отримання оптичної щільності 0,5 Mc Farland, яку визначали за допомогою денситометра Densi-La-Meter (PlivaLachema Diagnostika), потім розбавляли в 20 разів фізіологічним розчином. Мікробну суспензію в кінцевій концентрації $5 \times 10^{6}$ КУО/мл вносили по 100 мкл в лунки стерильних 96-лункових мікропланшетів. Лунки 3 рідким живильним середовищем без додавання мікробної суспензії використовували в якості негативного контролю. Для всіх контрольних і досліджуваних зразків дотримувалися 4-кратного повторення. Планшети закривали кришками та інкубували при $37^{\circ} \mathrm{C}$ протягом 24 год. У частину лунок додавали тільки 200 мкл бульйону без додавання бактеріальної суспензії. Подальші етапи для контрольних лунок були аналогічними досліджуваним.

Живильне середовище з планктонної формою бактерій видаляли, триразово лунки промивали 0,9\%м розчином $\mathrm{NaCl}$. Для фарбування біоплівки, що утворилася, у кожну лунку додавали 100 мкл 0,1 \%-го водного розчину генціанвіолету на 20 хв при кімнатній температурі. Барвник, який не зв'язався з біоплівкою, видаляли триразовим промиванням планшета ізотонічним розчином. Потім в кожну лунку вносили по 200 мкл 95 \%-го етанолу для підтвердження зв'язування генціанвіолету з утвореною біоплівкою. Біоплівкоутворення вивчали за допомогою спектрофотометричного аналізу (G. Toole, R. Kolter, 1998) на спектрофотометрі STAT FAX ${ }^{\circledR} 4300$ (Нідерланди) при довжині хвилі 620 нм. Інтенсивність забарвлення вмісту лунок відповідала ступеню біоплівкоутворення. Кількісним виразом ступеня утворення біоплівок служили значення оптичної щільності (ОЩ), які вимірювали на спектрофотометрі. Значущість відмінностей отриманих показників визначали за критерієм Стьюдента [6, 8].

Результати дослідження. Встановлено чіткі зони затримки росту культур $S$. aureus, що підтвер- 
джувало протистафілококову дію 0,5 \% бупівакаїну та 2,0\% лідокаїну. Ропівакаїн забезпечував слабкий протимікробний ефект, про що свідчила значно менша зона затримки росту, для якої в більшості випадків характерною була поява вторинного росту мікро- організмів навколо дисків 3 даним анестетиком. У бупівакаїну 0,25 \% встановлено помірні протимікробні властивості щодо S. aureus. Доведено переваги протимікробної активності препарату на основі декаметоксину (табл. 1).

Таблиця 1

\begin{tabular}{|c|c|c|c|c|c|c|}
\hline \multirow{2}{*}{ Мікроорганізми } & \multirow[b]{2}{*}{$\mathrm{n}$} & \multicolumn{5}{|c|}{$\begin{array}{l}\text { Зона затримки росту мікроорганізмів, мм } \\
(\mathbf{M} \pm \mathbf{m})\end{array}$} \\
\hline & & $\begin{array}{c}\text { Бупівакаїн } \\
0,5 \%\end{array}$ & $\begin{array}{c}\text { Лідокаїн } \\
2,0 \%\end{array}$ & $\begin{array}{c}\text { Ропівакаїн } \\
0,75 \%\end{array}$ & $\begin{array}{c}\text { Бупівакаїн } \\
0,25 \%\end{array}$ & $\begin{array}{l}\text { Декаметоксин } \\
0,01 \%\end{array}$ \\
\hline S. aureus & 31 & $12,0 \pm 3,4^{*}$ & $10,0 \pm 3,6^{*}$ & $8,0 \pm 2,3 * *$ & $10 \pm 2,8^{* *}$ & $24 \pm 2,3 * *$ \\
\hline
\end{tabular}

Примітки. ${ }^{*}$ - $\mathrm{p}<0,01,{ }^{*} *_{-} \mathrm{p}<0,001$ у порівнянні $з$ декаметоксином.

Для вивчення утворення біоплівок на поверхні лунок при дії анестетиків та антисептика декаметоксину проводили фарбування генціанвіолетом та вивчали ОЩ біоплівок кожного ізоляту S. aureus (табл. 2). Відносно до контрольної лунки оптичні шільності біоплівок розділяли на щільні, помірної щільності та низької щільності.

Таблиця 2

Характеристика впливу місцевих анестетиків та антисептика декаметоксину на біоплівкоутворення клінічних штамів $S$. aureus (в ОЩ)

\begin{tabular}{|c|c|c|c|c|c|c|c|c|}
\hline \multicolumn{2}{|c|}{ Мікроорганізми } & Контроль & $\begin{array}{c}\text { Ропівакаїн } \\
0,375 \%\end{array}$ & $\begin{array}{c}\text { Бупівакаїн } \\
0,125 \%\end{array}$ & $\begin{array}{c}\text { Бупівакаїн } \\
0,25 \%\end{array}$ & $\begin{array}{c}\text { Лідокаїн } \\
0,5 \%\end{array}$ & Лідокаїн 1\% & $\begin{array}{l}\text { Дека- } \\
\text { мето- } \\
\text { ксин }\end{array}$ \\
\hline \multirow[t]{3}{*}{$\begin{array}{l}\text { S. aureus } \\
(\mathrm{n}=31)\end{array}$} & $\mathrm{M} \pm \mathrm{m} *$ & $\begin{array}{c}0,244 \pm \\
0,006\end{array}$ & $\begin{array}{l}0,261 \pm \\
0,005\end{array}$ & $\begin{array}{c}0,212 \pm \\
0,001\end{array}$ & $\begin{array}{c}0,237 \pm \\
0,004\end{array}$ & $\begin{array}{c}0,216 \pm \\
0,001\end{array}$ & $\begin{array}{c}0,212 \pm \\
0,001\end{array}$ & $\begin{array}{c}0,208 \pm \\
0,001\end{array}$ \\
\hline & $\begin{array}{l}\min - \\
\max ^{* *}\end{array}$ & $\begin{array}{c}(0,204- \\
0,288)\end{array}$ & $\begin{array}{c}(0,280- \\
0,310)\end{array}$ & $(0,206-0,224)$ & $\begin{array}{l}(0,213- \\
0,257)\end{array}$ & $\begin{array}{l}(0,211- \\
0,221)\end{array}$ & $\begin{array}{l}(0,206- \\
0,231)\end{array}$ & $\begin{array}{c}(0,201 \\
- \\
0,214)\end{array}$ \\
\hline & $\mathrm{p}^{* * *}$ & - & $<0,05$ & $<0,001$ & $>0,05$ & $<0,001$ & $<0,001$ & $<0,001$ \\
\hline $\begin{array}{l}\text { Харак- } \\
\text { теристика } \\
\text { біоплівки }\end{array}$ & & контроль & щільна & $\begin{array}{c}\text { низька щіль- } \\
\text { ність }\end{array}$ & щільна & $\begin{array}{c}\text { низька } \\
\text { щільність }\end{array}$ & $\begin{array}{c}\text { низька } \\
\text { щільність }\end{array}$ & $\begin{array}{c}\text { низька } \\
\text { щіль- } \\
\text { ність }\end{array}$ \\
\hline
\end{tabular}

Примітки. *-середні значення та стандартне відхилення середнього; **_діапазон значень оптичної щільності від найменшого до найбільшого; ***_- в порівнянні з контролем.

Бактерицидні властивості щодо даних ізолятів проявляв лише антисептик декаметоксин у присутності концентрацій, що не перевищували 3,9 мкг/мл відповідно. Бактеріостатичну дію даного антисептика визначала в присутності $1,73 \pm 0,39$ мкг/мл. Визначили показник плівкоутворення

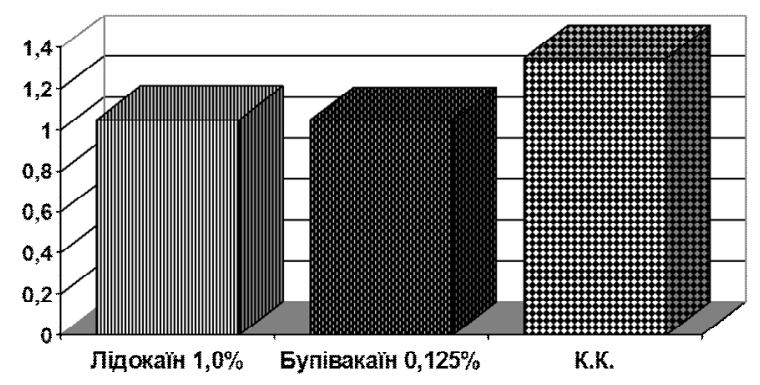

Встановлено, що середній показник плівкоутворення S. aureus $(1,054)$ зростав у присутності $0,375 \%$ ропівакаїну та $0,25 \%$ бупівакаїну в 1,308 та 1,206 раза відповідно (рис. 2).
S.aureus (1,345). Встановили, що в присутності 1,0\% лідокаїну та $0,125 \%$ бупівакаїну здатність утворювати біоплівки пригнічувалась в 0,778 та 0,776 раза відповідно (рис. 1).

Рис. 1. Зміна здатності до біоплівкоутворення клінічних штамів $\mathrm{S}$. aureus в присутності 1,0\% лідокаїну та $0,125 \%$ бупівакаїну (в одиницях оптичної щільності); К.К. - контроль культури

Загалом, зміну оптичної густини культури в присутності різних місцевих анестетиків та комбінації анестетиків 3 антисептиком декаметоксином демонструють рис. 3 та рис. 4 . 


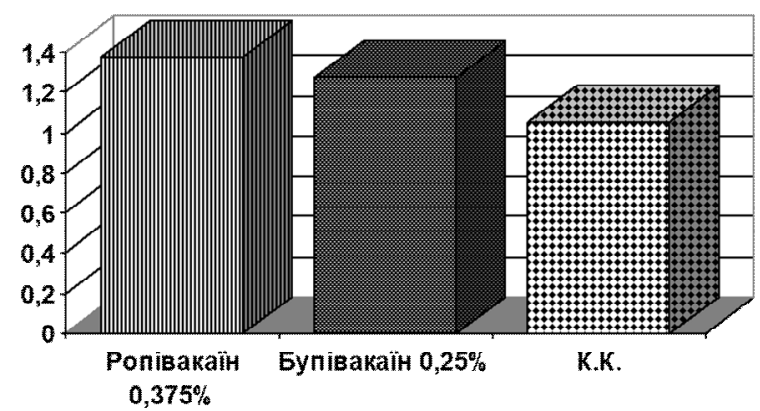

C S.aureus $12 \square$ S. aureus 24

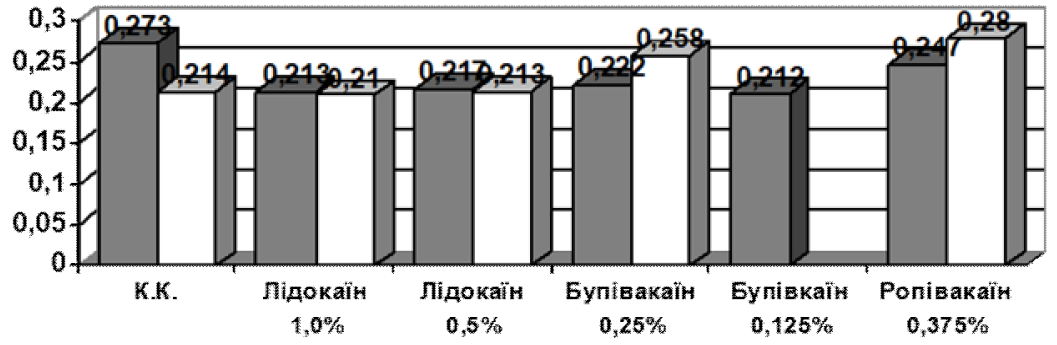

CS. aureus 12 C S. aureus 24

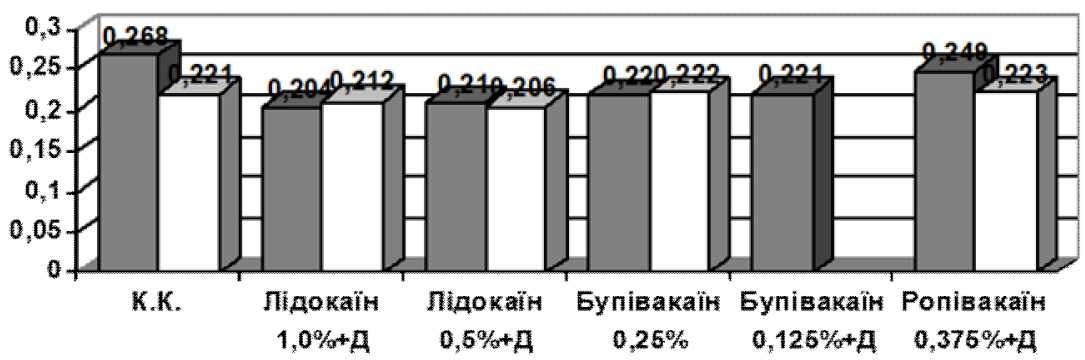

Доведено, що при одночасному застосуванні антисептика декаметоксину (1/4 мінімальної бактеріостатчиної концентрації) 3 анестетиками - відбувається посилення інгібуючого впливу останніх на біоплівкоутворення $S$. aureus.

Обговорення результатів. У наш час достеменно відомо, що інфекції, пов'язані з наданням медичної допомоги, часто спричиняються мікроорганізмами, які знаходяться у формі біоплівки. У таких умовах традиційна етіотропна терапія малоефективна [4]. Тому дослідники постійно проводять пошук альтернативних методів впливу на запальні процеси. У наших дослідженнях встановлено чутливість планктонних форм $S$. aureus до антисептика декаметоксину та місцевих анестетиків. Наші дослідження виявили що $S$. aureus чутливий до антисептика декаметоксину та анестетиків здебільшого у клінічних концетраціях. Встановлено виражений бактерицидний ефект декаметоксину, лідокаїну $2 \%$, бупавакаїну $0,5 \%$, та помірні бактеріостатичні властивості 0,25 \% бупівакаїну, ропівакаїну. Культури $S$. aureus, які були виділені зі зразків центральних венозних катетерів, характеризуються приблизно однаковою здатністю до плівкоутворення (табл. 2). Ці дослідження збігаються з даними про здатність до формування біоплівок стафілоко-
Рис. 2. Зміна здатності до плівкоутворення клінічного штаму S. aureus 23 в присутності $0,375 \%$ ропівакаїну та $0,25 \%$ бупівакаїну (в одиницях оптичної щільності); К.К. - контроль культури
Рис. 3. Зміна оптичної щільності при формуванні біоплівок двома клінічними штамами S. aureus в присутності місцевих анестетиків різної концентрації; К.К. - контроль культури

Рис. 4. Зміна оптичної густини при формуванні біоплівок двома клінічними штамами S.aureus в присутності місцевих анестетиків різної концентрації в посднанні 3 антисептиком декаметоксином; К.К. - контроль культури ками у 51,5 \% випадків, причому у коагулазопозитивних стафілококів вона достовірно вища $(\mathrm{p}<0,05)$, ніж у коагулазонегативних стафілококів [16]. При дослідженні як планктонних, так і біоплівкових форм S. aureus до антисептика прослідковувався виражений протимікробний ефект та низька щільність біоплівки $(0,212 \pm 0,010)$. При дослідженні ефективності місцевих анестетиків як щодо планктонних, так і до плівкових форм $S$. aureus: анестетики в клінічних концентраціях проявляли протимікробний ефект та чинили супресивну дію на здатність стафілокока продукувати біоплівку, про що свідчили низькі показники щільності біоплівки в присутності 0,5\% бупівакаїну, $1 \%$ лідокаїну. При використанні $0,375 \%$ ропівакаїну визначили резистентність клінічних штамів $S$. aureus, які утворювали щільну біоплівку в присутності даного анестетика.

\section{Висновки:}

1. Клінічні штами S. aureus з вираженими біоплівкоутворюючими властивостями, які колонізують полімерні поверхні медичних засобів, володіють високою чутливістю до антисептика декаметоксину; пригнічують свій ріст і розмноження в присутності клінічних концентрацій сучасних місцевих анестетиків 
(бупівакаїн 0,5 \%, лідокаїн 2,0\%), які використовуються в сучасній медичній практиці.

2. Лікарський засіб для місцевої анестезії ропівакаїн забезпечує слабку бактеріостатичну дію щодо золотистого стафілокока, одним з проявів стійкості клінічних ізолятів якого $є$ активна продукція щільної біоплівки в присутності даного місцевого анестетика амідного типу.

3. Комбіноване застосування антисептика декаметоксину (1/4 мінімальної бактеріостатчиної концентрації) 3 анестетиками потенціює інгібуючий вплив останніх на біоплівкоутворення $S$. aureus.

\section{References:}

1. Pedersen RM, Grønnemose RB, Stærk K, Asferg CA, Andersen TB, Kolmos HJ, et al. A method for quantification of epithelium colonization capacity by pathogenic bacteria. Frontiers in cellular and infection microbiology. 2018; 8:16.

2. Phuong NTM, Van Quang N, Mai TT, Anh NV, Kuhakarn C, Reutrakul V, et al. Antibiofilm activity of $\alpha$-mangostin extracted from Garcinia mangostana L. against Staphylococcus aureus. Asian Pacific journal of tropical medicine. 2017; 10(12):1154-60. DOI: 10.1016/j.apjtm.2017.10.022

3. Hogan S, O'Gara JP, O'Neill. Novel treatment of Staphylococcus aureus device-related infections using fibrinolytic agents. Antimicrobial agents and chemotherapy. 2018; 62(2):14-7.

4. Banin E, Hughes D, Kuipers OP. Bacterial pathogens, antibiotics and antibiotic resistance. FEMS microbiology reviews. 2017; 41(3):450-52. DOI:10.1093/femsre/fux016

5. Sugimoto S, Sato F, Miyakawa R, Chiba A, Onodera $\mathrm{S}$, Hori S, et al. Broad impact of extracellular DNA on biofilm formation by clinically isolated Methicillinresistant and-sensitive strains of Staphylococcus aureus. Scientific reports. 2018; 8(1):1-11.

6. Zapotoczna M, Forde É, Hogan S, Humphreys H, O'Gara JP, Fitzgerald-Hughes D, et al. Eradication of Staphylococcus aureus biofilm infections using synthetic antimicrobial peptides. The Journal of infectious diseases. 2017; 215(6):975-83.

7. Midlenko VI. Chutlyvist do preparativ bakteriofahiv zbudnykiv uskladnen u khvorykh pislya travm i operatyvnykh vtruchan na oporno-rukhovoho apparati. Fundamentalnye doslidzhennya. 2013; 9:871-74.

8. Zapotoczna M, O'Neill E, O'Gara JP. Untangling the diverse and redundant mechanisms of Staphylococcus aureus biofilm formation. PLoS pathogens. 2016; 12(7):1-6.

9. Holt J, Krieg N, Sneath P. Opredelitel bakteriy Berdzhi. Moscow: Mir; 1997. P.368.

10. Gnanamani A, Hariharan P, Paul-Satyaseela M. Staphylococcus aureus: Overview of bacteriology, clinical diseases, epidemiology, antibiotic resistance and therapeutic approach. Frontiers in Staphylococcus aureus. 2017; 4:28.

11. Wang L, Ruan S. Modeling nosocomial infections of methicillin-resistant Staphylococcus aureus with environment contamination. Scientific reports. 2017; 7(1):1-12. DOI: 10.1038/s41598-017-00261-1
12. Wang H, Liu Y, Sun H, Xu Y, Xie X, Chen M. In vitro activity of ceftobiprole, linezolid, tigecycline, and 23 other antimicrobial agents against Staphylococcus aureus isolates in China. Diagnostic microbiology and infectious disease. 2008; 62(2):22629. DOI: 10.1016/j.diagmicrobio.2008.06.003.

15. Kovalchuk VP, Kondratiuk VM, Fomina NS, Kovalenko IM. Microbiological substantiation of expediency of combined use of antibiotics and Decasan. Emergency medicine. 2017; 8(87):39-42.

16. Razavi BM, Fazly Bazzaz BS. A review and new insights to antimicrobial action of local anesthetics. Eur J Clin Microbiol Infect Dis. 2019; 38:991-1002. DOI: $10.1007 / \mathrm{s} 10096-018-03460-4$

\section{УДК 615.281.9 / 615.076.7 \\ ИССЛЕДОВАНИЕ ЧУВСТВИТЕЛЬНОСТИ КЛИНИЧЕСКИХ ШТАММОВ S. AUREUS К АНТИСЕПТИКУ ДЕКАМЕТОКСИН И МЕСТНЫХ АНЕСТЕТИКОВ}

Ю.Н. Бабина ${ }^{1}$, А.А. Назарчук ${ }^{2}$, Д.В. Дмитриев ${ }^{1,3}$, О.В. Римша ${ }^{2}$, М.А. Бегма ${ }^{2}$

Винницкий нацииональный медицинский университет им. М.И. Пирогова,

${ }^{I}$ кафедра анестезиологии, интенсивной терапии $u$ неотложных состояний,

${ }^{2}$ кафедра микробиологии;

${ }^{3}$ Винниикий областной клинический высокоспецииализи рованный эндокринологический изентр,

2. Виннища, Украина,

ORCID ID: 0000-0003-4399-5178,

e-mail: ulianababina1989@gmail.com,

ORCID ID: 0000-0001-7581-0938,

e-mail: nazarchukoa@gmail.com,

ORCID ID: 0000-0001-6067-681X,

e-mail:dmytrodmytriiev@gmail.com,

ORCID ID: 0000-0002-2718-0246,

e-mail:rymsha_av@ukr.net,

ORCID ID: 00000-0001-8433-9420

Резюме. Известно, что около 65-85 \% всех инфекционных заболеваний вызванные бактериями, которые обладают способностью к формированию биопленок.

Цель исследования - изучить формирование биопленок in vitro штаммами $\mathrm{S}$. aureus и определить их чувствительность к местным анестетикам отдельно и в комбинации с антисептиком декаметоксином.

Методы. Активность местных анестетиков (бупивакаин 0,5\%, лидокаин $2 \%$, ропивакаин 0,75\%) исследовали на клинических штаммах S. aureus (n = 31) качественным диско-диффузным методом с использованием стандартных стерильных бумажных дисков. В качестве контроля использовали антисептик декаметоксин 0,01 \%. Изучено действие анестетиков на способность S. aureus производить биопленки в присутствии клинических концентраций анестетиков на полиуретановых катетеры и по оптической плотности (ОЩ) биопленок в 96-луночном планшете 
c покраской кристалл-виолеттом (по Christensen, 1985).

Результаты. Локальные анестетики проявляли противостафилококковое действие, но уступали противомикробному действию декаметоксину. В присутствии 1,0 \% лидокаина и 0,125 \% бупивакаина имело место подавление пленкообразования S. aureus в 0,778 и 0,776 раз, а средний показатель пленкообразования S. aureus рос в присутствии $0,375 \%$ ропивакаина и $0,25 \%$ бупивакаина в 1,308 и 1,206 раз соответственно.

Выводи. Культура S. aureus обладает способностью к формированию биопленок на медицинских изделиях. Клинические штаммы условнопатогенных микроорганизмов S. aureus, которые колонизируют полимерные поверхности медицинских средств, обладают высокой чувствительностью к декаметоксину. Местные анестетики бупивакаин, лидокаин имеют выраженные антимикробные свойства к изолятам S. aureus, подавляют образование ими бактериальной биопленки, по сравнению с низким антистафилококковым действием ропивакаина.

Ключевые слова: анестетики, антисептики, биопленка, микроорганизмы, S. aureus.

\section{UDC 615.281.9 / 615.076.7 \\ RESEARCH OF SENSITIVITY OF CLINICAL STRAINS OF S. AUREUS TO DECAMETHOXIN AND LOCAL ANESTHETICS}

Y.M. Babina ${ }^{1}$, O.A. Nazarchuk ${ }^{2}$, D.V. Dmytriievev, O.V. Rymsha ${ }^{2}$, M.A. Behma ${ }^{2}$

National Pirogov Memorial Medical University, Vinnytsya,

${ }^{I}$ Department of Microbiology, Vinnytsya, Ukraine,

${ }^{2}$ Department of Anesthesiology, Intensive care and Emergency Medicine;

${ }^{3}$ Vinnitsya Regional Clinical Highly Specialized

Endocrinological Center, Vinnytsya, Ukraine,

ORCID ID: 0000-0003-4399-5178,

e-mail: ulianababina1989@gmail.com,

ORCID ID: 0000-0001-7581-0938,

e-mail:nazarchukoa@gmail.com,

ORCID ID: 0000-0001-6067-681X,

e-mail:dmytrodmytriiev@gmail.com,

ORCID ID: 0000-0002-2718-0246,

e-mail:rymshaav@ukr.net,

ORCID ID: 0000-0001-8433-9420

Abstract. The formation of biofilms by pathogenic microorganisms $\mathrm{S}$. aureus increases the risk of infectious lesions of different localization in surgical patients. However, about $65-85 \%$ of all infectious diseases caused by bacteria, which have the ability to form biofilms. There was found that large number of complications after the use of catheters, other implantable medical materials and equipment were closely related to the abil- ity of pathogens to form biofilms. Microorganisms included in a biofilm have a higher resistance to antimicrobial agents, than the same bacteria that live outside such structures. Regarding this, the search and study of drugs, which can suppress the formation of biofilms by microorganisms and destroy them within such microbial communities is an integral and relevant part of antimicrobial therapy.

Objective. The aim of the research was to study the formation of mono-species biofilms in vitro by $S$. aureus strains and further determine their sensitivity to local anesthetics separately and in combination with the antiseptic decamethoxin.

Materials and methods. The activity of local anesthetics (bupivacaine $0.5 \%$, lidocaine $2 \%$, ropivacaine $0.75 \%)$ was studied on clinical strains of S. aureus $(n=$ 31) using a qualitative disco-diffusion method using standard sterile paper disks soaked with ex tempore clinical doses of drugs. An antiseptic decamethoxin $0.01 \%$ was used as a control. Zones of growth inhibition of microorganisms around discs with anesthetics and decamethoxin on solid nutrient media were measured after 24 $\mathrm{h}$ of incubation of cultures of microorganisms $\left(\mathrm{t} 37^{\circ} \mathrm{C}\right)$. Additionally, the effect of anesthetics on the ability of S. aureus to produce biofilms was studied in the presence of clinical concentrations of local anesthetics on polyurethane catheters and the optical density (OR) of biofilms in a 96-well plate followed by crystal-violet staining (according to Christensen, 1985).

Results. Researches have shown the effect of local anesthetics against staphylococcus, but inferior to the antimicrobial effect of the antiseptic decamethoxin. There was found that in the presence of $1.0 \%$ lidocaine and $0.125 \%$ bupivacaine, the formation of biofilm by S. aureus was suppressed by 0.778 and 0.776 times, respectively, and the average film formation of S. aureus increased in the presence of $0.375 \%$ ropivacaine and $0.25 \%$ bupivacaine in 1.308 and 1.206 times, respectively. It is studied that when using the antiseptic decamethoxine (1/4 of the minimum bacteriostatic concentration) with anesthetics - there is an increase in the inhibitory effect of anesthetics on the biofilm formation of S. aureus.

Conclusions. The S. aureus culture has an ability to form biofilms on medical devices. Clinical strains of conditionally pathogenic microorganisms S. aureus that colonize the polymer surfaces of medical devices are highly sensitive to the antiseptic decamethoxin. Local anesthetics bupivacaine, lidocaine have pronounced antimicrobial properties for S. aureus isolates, inhibiting their formation of a bacterial biofilm. In the presence of $0.375 \%$ ropivacaine strains of $\mathrm{S}$. aureus formed a dense biofilm, which confirmed the resistance of this strain to ropivacaine. Ropivacaine provides a weak bacteriostatic effect only on the planktonic form of Staphylococcus aureus.

Keywords: anesthetics, antiseptics, biofilm, microorganisms, S. aureus. 